\title{
Effects of Temperature on the Development of Chinese Windmill Butter- fly, Atrophaneura alcinous (Lepidoptera: Papilionidae)
}

\author{
Seong-Hyun Kim*, Seong-Jin Hong, Hae-Chul Park, Young-Bo Lee, and Nam Jung Kim \\ Department of Agricultural Biology, National Academy of Agricultural Science, Suwon 441-100, Korea.
}

(Received 27 September 2012; Accepted 16 December 2012)

The Chinese windmill butterfly, Atrophaneura alcinous, is an important butterfly for exhibition in butterfly garden. The objective of this study was to determine the effect of temperature on $A$. alcinous in the laboratory. Development of $A$. alcinous reared on leaves of Aristolochia contorta was investigated at five constant the laboratory condition $(20,22.5,25,27.5$ and $30^{\circ} \mathrm{C}$ ) and at relative humidity of $60 \%$ with a photoperiod of 14:10 (L:D). Temperatures have been suggested as an important determinant of developmental rate, lifespan and mortality in invertebrates. As the temperature increased, the length of the developmental period gradually decreased. The developmental time (pupation) from egg hatching to pupation was respectively $25.8,23.6,19.6,15.5$, and 12.9 days at the temperatures of $20,22.5,25,27.5$ and $30^{\circ} \mathrm{C}$. And pupation was respectively $40.0,30.0,63.4,50.0,23.3 \%$ at the temperatures of $20,22.5,25,27.5$ and $30^{\circ} \mathrm{C}$. The developmental threshold temperature estimated for egg-to-pupae was 10.8 , with a thermal constant of 230.4 degree-days. Therefore, the optimal developmental temperature for $A$. alninous was determined to be $25^{\circ} \mathrm{C}$. To compare the effects of the total duration of chilling on the termination of diapause, larvae were subjected to a temperature of $8^{\circ} \mathrm{C}$ from 60 to 120 days. The rate of termination of diapause was significantly higher at 60 days compared to other incubation period.

Key words: Atrophaneura alcinous, Aristolochia contorta, Diapauses

\footnotetext{
*To whom the correspondence addressed Department of Agricultural Biology, National Academy of Agricultural Science, RDA, Suwon 441-100, Korea. Tel: +82-31-290-8560; E-mail:ichibbang@korea.kr http://dx.doi.org/10.7852/ijie.2012.25.2.159
}

\section{Introduction}

The Chinese windmill butterfly Atrophaneura alcinous Klug (Papilionidae) feeds on the plant family Aristolochiaceae. Many plants in this family contain aristolochic acids, which are toxic alkaloids (Chen and Zhu, 1987). The host plant contains toxic substances that help the butterfly to maintain a high population density by allowing escaping the butterflies from predation. These butterflies may completely defoliate the host. Because the harmful substances are also feeding and oviposition stimulants for the butterfly, the starved larvae are frequently cannibalistic (Nishida and Fukami, 1989a, b). Adult male Atrophaneura alcinous emit a strong characteristic odor that is perceivable by humans, although the females of the insects are almost scentless. It has been shown that particular exocrine substances of certain male butterflies are sex pheromones and act as aphrodisiacs or arrestants, inducing the females to copulate (Myers and Brower, 1969; Pliske and Eisner, 1969; Lundgren and Bergström, 1975).

During the larval stages, the life cycle of this species depends on various environmental factors, such as photoperiod, temperature and food plants, as well as geographical factors, such as latitude and altitude (Kato, 2005). The rate of insect development depends upon the temperature to which the insects are exposed. The amount of heat required over time for an insect to complete specified aspects of development is termed the thermal constant (Andrewartha and Birch, 1954)

Many insect studies rely on laboratory-reared individuals. Providing information on how to successfully rear selected insects in the laboratory has long been a fundamental research goal (Cohen, 2003). A practical difficulty in working with butterflies is that many are active only part of the year. Moreover, their larval host plants are often seasonal. For this reason, artificial diets for insects are essential research tools. A wide range of commercial 
diets are available, as well as published formulations. These diets have been developed to maximize insect growth and reproduction by meeting or surpassing the insects' minimum nutritional requirements. This study investigated the effects of temperature and diet on the developmental and life cycle of $A$. alcinous from Korea.

\section{Materials and Methods}

\section{Experimental insects}

Laboratory colonies of $A$. alcinous were established from adults collected at their overwintering sites on 15 May 2007 and 15 July 2008. For the larval stage the diet for the species is Aristolochia contorta. The insects were maintained at $25^{\circ} \mathrm{C}$ and $65 \%$ relative humidity under a photoperiod of LD 16:8hrs. The hatched larvae were individually reared in Petri dishe. The containers used for rearing included small Petri dishes $(35 \times 10 \mathrm{~cm})$ for the $1^{\text {st }}$ and $2^{\text {nd }}$ stages, medium Petri dishes $(60 \times 1.5 \mathrm{~cm})$ for the $3^{\text {rd }}$ and $4^{\text {th }}$ stages, and large Petri dishes $(100 \times 40 \mathrm{~cm})$ for the $5^{\text {th }}$ stage.

\section{Effects of temperature on developmental characteristics}

The effect of constant rearing temperatures on the developmental period of A. alcinous was tested at 20, 22.5, 25, 27.5 and $30^{\circ} \mathrm{C}$ (LD 14:10 hrs). Aristolochia contorta leaves were provided to hatched larvae. The larval period and the survival rate were then determined. Newly hatched larvae were placed on A. contorta plants under various temperatures. The larvae were examined daily, and food was added as needed. Observations were conducted daily to measure the survival and developmental time of each larva until the adult emerged. A linear model was applied to estimate the temperature-dependent development of $A$. alcinous on A. contorta.

\section{Linear model}

$\mathrm{DD}=\mathrm{d}(\mathrm{T}-\mathrm{DT})$

In this model, DT is the developmental threshold temperature and (DD) is the effective temperature Campbell et al., 1974; Obrycki and Tauber 1982; Jarošik et al., 2002; Kontodimas et al., 2004

\section{Respirometry}

The pupae of $A$. alcinous were allowed $5 \mathrm{hrs}$ of acclimation in clear glass containers $(30 \sim 60 \mathrm{ml})$ within the chamber. The rates of $\mathrm{O}_{2}$ consumption were measured at 30 min intervals with a Micro-Oxymax System (Columbus Instruments, USA). The Micro-Oxymax System is a closed system with a reference chamber that recalibrates the sensors after each measurement and normalizes the rates of $\mathrm{O}_{2}$ consumption to standard temperature $\left(20^{\circ} \mathrm{C}\right)$ and pressure $(760 \mathrm{~mm} \mathrm{Hg})$. The air in the chambers was refreshed after each measurement to maintain constant $\mathrm{O}_{2}$ and $\mathrm{CO}_{2}$ concentrations. The $\mathrm{O}_{2}$ uptake was expressed in units of $\mathrm{mol} / \mathrm{ml} / \mathrm{g} / \mathrm{min}$. Each value of oxygen uptake represents the mean of 3 replicates.

\section{Diapause termination}

To prepare diapausing insects, newly hatched larvae were individually placed in a Petri-dish $(65 \times 15 \mathrm{~cm})$ with $A$. contorta and reared continuously under LD 8:16 hrs at $20^{\circ} \mathrm{C}$. Diapausing individuals at $5,10,15,20$, and 30 days after the final molt were used in the experiments to determine the sequence of diapause development during these periods. The diapausing larvae were chilled at $8^{\circ} \mathrm{C}$ for 60 , 70,90 and 105 days and thereafter maintained at $25^{\circ} \mathrm{C}$. Throughout these treatments, the photoperiod was LD 16:8 hrs. The survival rate of the larvae after cold treatment was observed in association with the termination of diapause.

\section{Statistical analysis}

Differences in development and diapause were tested with an analysis of variance (ANOVA). If significant differences were detected, multiple comparisons were performed with a Tukey HSD multiple range test.

\section{Results and Discussion}

\section{Effect of temperature on the development of $A$. alcinous}

A. alcinous larvae were reared at various temperatures to determine the effects of temperature variation on development. The survival rates of $A$. alcinous at the 5 different temperatures used are shown in Table 1. These survival rates were $40.0,30.0,63.4,50$ and $23.3 \%$ at $20,22.5,25$, 27.5 and $30^{\circ} \mathrm{C}$, respectively. The effect of these constant temperatures on the larval developmental time is summarized in Table 1 and Table 2. The mean duration of development, 12.9 days, was shortest at $30^{\circ} \mathrm{C}$. The duration of each instar was greater at relatively low temperatures than at higher temperatures (Egg: $F_{4,87}=12.247, p<0.0001$; $1^{\text {st }}$ instar: $F_{4,63}=35.412, p<0.0001 ; 2^{\text {nd }}$ instar: $F_{4,59}=$ 14.751, $p<0.0001 ; 3^{\text {rd }}$ instar: $F_{4,58}=7.987, P<0.0001$; $4^{\text {th }}$ instar: $F_{4,57}=13.214, p<0.0001 ; 5^{\text {th }}$ instar: $F_{4,57}=$ $7.347, p<0.0001$; total larvae: $F_{4,58}=23.510, P<0.0001$; full development (from egg to pupae): $F_{4,57}=46.162, p<$ $0.0001)$. The developmental rate increased linearly with increasing temperature within the experimental temperature range (Table 2), as is generally the case in insects. 
Table 1. Developmental characteristics of $A$. alcinous at different rearing temperatures

\begin{tabular}{|c|c|c|c|c|c|c|c|c|c|}
\hline \multirow[b]{2}{*}{$\begin{array}{l}\text { Temp. } \\
\left({ }^{\circ} \mathrm{C}\right)\end{array}$} & \multicolumn{2}{|l|}{ Egg } & \multicolumn{5}{|c|}{ Larvae } & \multirow{2}{*}{$\begin{array}{c}\text { Total larval } \\
\text { duration } \\
\text { (days) }\end{array}$} & \multirow[b]{2}{*}{$\begin{array}{c}\text { Pupation } \\
(\%)\end{array}$} \\
\hline & $\begin{array}{c}\text { Duration } \\
\text { (days) }\end{array}$ & $\begin{array}{c}\text { Hatching } \\
\text { rate }(\%)\end{array}$ & $1^{\text {st }}$ & $2^{\text {nd }}$ & $3^{\text {rd }}$ & $4^{\text {th }}$ & $5^{\text {th }}$ & & \\
\hline 20 & $4.9 \pm 0.2^{\mathrm{b}}$ & $63.3^{\mathrm{b}}$ & $6.3 \pm 0.2^{\mathrm{d}}$ & $4.7 \pm 0.2^{\mathrm{d}}$ & $4.7 \pm 0.2^{b}$ & $4.1 \pm 0.2^{b}$ & $6.2 \pm 0.2^{b}$ & $25.8 \pm 0.0^{c}$ & $40.0^{\mathrm{a}}$ \\
\hline 22.5 & $5.8 \pm 0.2^{\mathrm{b}}$ & $56.7^{\mathrm{b}}$ & $5.0 \pm 0.2^{\mathrm{c}}$ & $4.5 \pm 0.2^{\mathrm{cd}}$ & $4.3 \pm 0.2^{\mathrm{b}}$ & $3.8 \pm 0.3^{\mathrm{b}}$ & $6.2 \pm 0.2^{\mathrm{b}}$ & $23.6 \pm 0.0^{\mathrm{b}}$ & $30.0^{\mathrm{a}}$ \\
\hline 25 & $3.3 \pm 0.2^{\mathrm{a}}$ & $86.7^{\mathrm{a}}$ & $3.7 \pm 0.3^{\mathrm{b}}$ & $3.7 \pm 0.3^{\mathrm{bc}}$ & $3.7 \pm 0.3^{\mathrm{ab}}$ & $3.2 \pm 0.3^{\mathrm{ab}}$ & $5.8 \pm 0.2^{\mathrm{a}}$ & $19.6 \pm 0.1^{\mathrm{b}}$ & $63.4^{\mathrm{b}}$ \\
\hline 27.5 & $3.2 \pm 0.2^{\mathrm{a}}$ & $66.7^{\mathrm{b}}$ & $2.7 \pm 0.4^{\mathrm{a}}$ & $3.3 \pm 0.3^{\mathrm{b}}$ & $2.8 \pm 0.4^{\mathrm{a}}$ & $2.7 \pm 0.4^{\mathrm{a}}$ & $4.2 \pm 0.2^{\mathrm{a}}$ & $15.5 \pm 0.1^{\mathrm{a}}$ & $50.0^{\mathrm{b}}$ \\
\hline 30 & $3.3 \pm 0.2^{\mathrm{a}}$ & $30.0^{\mathrm{c}}$ & $2.5 \pm 0.4^{\mathrm{a}}$ & $2.3 \pm 0.4^{\mathrm{a}}$ & $2.6 \pm 0.4^{\mathrm{a}}$ & $2.7 \pm 0.4^{\mathrm{a}}$ & $3.0 \pm 0.3^{\mathrm{a}}$ & $12.9 \pm 0.1^{\mathrm{a}}$ & $23.3^{\mathrm{a}}$ \\
\hline
\end{tabular}

Hatching larvae of $A$. alcinous subjected to different temperatures $\left(17.5,20,22.5,25,27.5\right.$ and $\left.30^{\circ} \mathrm{C}\right)$. Values followed by the same letters within a column do not differ significantly (Tukey test following ANOVA, $p>0.05$ ).

Table 2. Developmental threshold temperature (DT) and effective temperature (DD) for larval and pupal stages of $A$. alcinous

\begin{tabular}{|c|c|c|c|c|}
\hline Developmental stage & Regression Equation $^{1)}$ & $r^{2}$ & DT $\left({ }^{\circ} \mathrm{C}\right)$ & DD (degree-days) \\
\hline Egg & $y=0.0206 x-0.2973$ & 0.81 & 14.4 & 44.8 \\
\hline 1st instar & $y=0.0259 x-0.3674$ & 0.97 & 14.2 & 38.5 \\
\hline 2nd instar & $y=0.021 x-0.2362$ & 0.86 & 11.2 & 48.1 \\
\hline 3rd instar & $y=0.0187 x-0.1768$ & 0.95 & 9.45 & 53.3 \\
\hline 4th instar & $y=0.0144 x-0.0481$ & 0.94 & 3.3 & 69.7 \\
\hline 5 th instar & $y=0.0168 x-0.2076$ & 0.80 & 12.3 & 106.0 \\
\hline Egg to pupation & $y=0.0031 x-0.0334$ & 0.93 & 10.8 & 230.4 \\
\hline
\end{tabular}

1) $\mathrm{y}=\mathrm{ax}+\mathrm{b}$, where $\mathrm{y}$ is developmental rate and $\mathrm{x}$ is temperature.

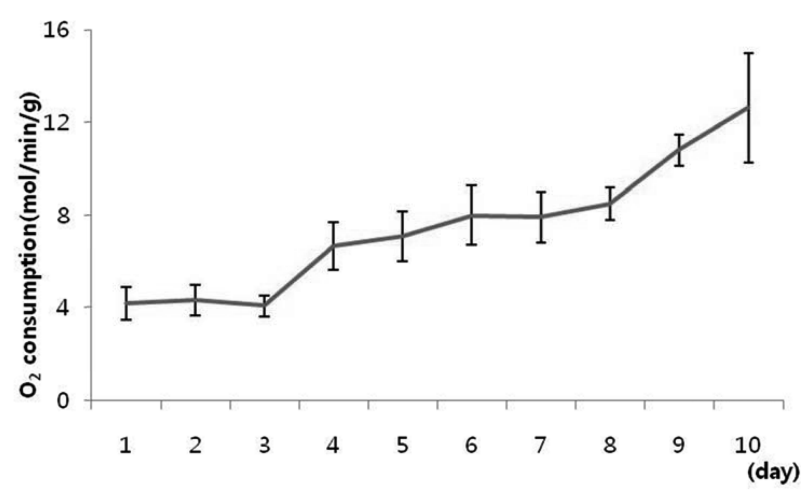

Fig. 1. Oxygen consumption by developing pupae of Atrophaneura alcinous from pupation until final diapause. The pupae were reared at LD 16:8 $\mathrm{h}$ and incubated at $25^{\circ} \mathrm{C}$.

The lower developmental threshold temperature was estimated to be $10.8^{\circ} \mathrm{C}$, and the estimated thermal constant was 230.4 degree-days for the larvae (Table 2). The coefficients of determination $\left(r^{2}\right)$ exceeded 0.850 except for the egg and the $5^{\text {th }}$-instar larvae.

\section{Diapause termination}

The oxygen consumption of pupae was compared with that of non-diapausing pupae at the same stage, and the

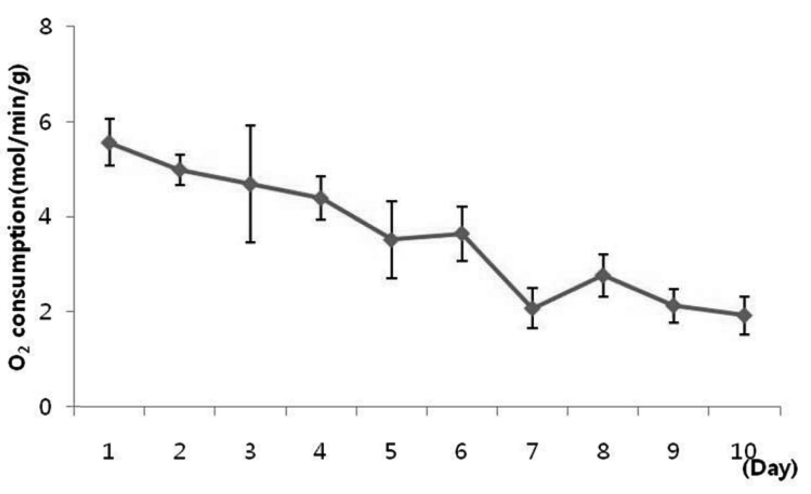

Fig. 2. Oxygen consumption by developing pupae of Atrophaneura alcinous from pupation until final diapause. The pupae were reared at $\mathrm{LD} 8: 16 \mathrm{~h}$ and incubated at $20^{\circ} \mathrm{C}$.

oxygen consumption of pupae in the final diapause stage was compared with that of pupae at the beginning of that stage (Fig. 1, Fig. 2). Usually, oxygen consumption by diapausing insects is lower than that of the corresponding active stage. There are, however, considerable differences between species. Generally, the diapausing stages of insects consume between 5 and $70 \%$ as much oxygen as the corresponding active stages (Hayes et al., 1968; Adamek and Fischer, 1985). Thus, a decrease in oxygen 
Table 3. Development of Atrophaneura alcinous after storage at low temperature for diapause termination

\begin{tabular}{cccc}
\hline Day & $\begin{array}{c}\text { Days from diapause } \\
\text { termination to } \\
\text { emergence (days) }\end{array}$ & $\begin{array}{c}\text { Emergence rate } \\
(\%)\end{array}$ & $\begin{array}{c}\text { Crippled wing } \\
(\%)\end{array}$ \\
\hline 60 & $18.3 \pm 6.3^{\mathrm{b}}$ & $80.7^{\mathrm{a}}$ & $21.1^{\mathrm{a}}$ \\
75 & $10.0 \pm 1.6^{\mathrm{a}}$ & $57.1^{\mathrm{c}}$ & $25.0^{\mathrm{a}}$ \\
90 & $10.5 \pm 1.4^{\mathrm{a}}$ & $71.6^{\mathrm{b}}$ & $9.5^{\mathrm{a}}$ \\
105 & $9.7 \pm 0.2^{\mathrm{a}}$ & $73.2^{\mathrm{ab}}$ & $12.2^{\mathrm{a}}$ \\
\hline
\end{tabular}

Values followed by the same letters within a column do not differ significantly (Tukey test following ANOVA, $\mathrm{P}>0.05$ ).

consumption is sometimes used as evidence for the incidence of diapause (Gehrken, 1985).

Studies on the developmental control of diapause termination have been performed using butterfly species belonging to different families, including Papilio xuthus, P. polyxenes (Papilionidae) and Pieris rapae (Pieridae). To investigate the environmental cues affecting the diapause termination of $A$. alcinous, hatching larvae reared under short day conditions at $20^{\circ} \mathrm{C}$ were transferred and allowed to terminate diapause at different temperatures. Chilling has been shown to accelerate the termination of diapause in certain species (Lees, 1955). The effect of exposure to low temperature on the rate of diapause development of the Chinese windmill butterfly was examined. The effect of chilling at different temperatures on diapause termination is shown in Table 3. Diapausing larvae were chilled for 60 days at $8^{\circ} \mathrm{C}$ and thereafter subjected to LD $16: 8 \mathrm{~h}$ at $25^{\circ} \mathrm{C}$ (Table 3). The most suitable chilling temperature was 60 days $\left(F_{3,7}=19.840, p<0.001\right)$. In conclusion, temperature had significant effects of $A$. alcinous. Optimal developmental temperature for the $\mathrm{A}$. alcinous was $25^{\circ} \mathrm{C}$.

\section{Acknowledgment}

This study was carried out with the support of the Research Program for Agricultural Science \& Technology Development (PJ907019), National Academy of Agricultural Science, Rural Development Administration, Republic of Korea.

\section{References}

Adamek G, Fischer J (1985) The oxygen consumption of nondormant and dormant larvae of Chironomus plumosus
(Diptera). J Insect Physiol 31, 767-772.

Andrewartha HG, Birch LC (1954) The Distribution and Abundance of Animals. Chicago Univ Press, Chicago and London.

Campbell A, Frazer BD, Gilbert N, Gutierrez NP, Mackauer M (1974) Temperature requirements of some aphids and their parasites. J Appl Ecol 11, 431-438.

Chen ZL, Zhu DY (1987) Aristolochia alkaloids, pp. 29-65, in A. brossi (ed.). The Alkaloids: Chemistry and Pharmacology. Academic Press, San Diego.

Cohen AC (2003) Insect Diets: Science and Technology, CRC Press, NY.

Gehrken U (1985) Physiology of diapause in the adult bark beetle, Ips acuminatus Gyll., studied in relation to cold hardiness. J Insect Physiol 31, 909-916.

Hayes DK, Schechter MS, Mensing E, Horton J (1968) Oxygen uptake of single insects determined with a polarographic oxygen electrode. Anal Biochem 26, 51-60.

Jarošík V, Honik A, Anthony FGD (2002) Developmental rate isomorphy in insects and mites. Amer Nat, 160, 497-510.

Kato Y (2005) Geographic variation in photoperiodic response for the induction of pupal diapause in the Aristolochia-feeding butterfly Atrophaneura alcinous. Appl Entomol Zool 40, 347-350.

Kontodimas DC, Eliopoulos PA, Stathas GJ, Economou LP (2004) Comparative Temperature-Dependent Development of Nephus includens (Kirsch) and Nephus bisignatus (Boheman) (Coleoptera: Coccinellidae) Preying on Planococcus citri (Risso) (Homoptera: Pseudococcidae): Evaluation of a Linear and Various Nonlinear Models Using Specific Criteria. Environ Entomol 33, 1-11.

Lees AD (1955) The Physiology of Diapause in Arthropods. Cambridge Univ, Cambridge.

Lundgren L, Bergström G (1975) Wing scents and scentreleased phases in the courtship behavior of Lycaeides argyrognomon (Lepidoptera: Lycaenidae). J Chem Ecol 1, 399412.

Myers J, Brower LP (1969) A behavioural analysis of the courtship pheromone receptors of the Queen butterfly, Danaus gilippus berenice. J Insect Physiol 15, 2117-2130.

Nishida R, Fukami H (1989a) Ecological adaptation of an aristolochiaceae-feeding swallowtail butterfly, Atrophaneura alcinous, to aristolochic acids. J Chem Ecol 15, 2549-2563.

Nishida R, Fukami H (1989b) Oviposition stimulants of an aristolochiaceae-feeding swallowtail butterfly, Atrophaneura alcinous. J Chem Ecol 15, 2565-2575.

Obrycki JJ, Tauber MJ (1982) Thermal requirements for development of Hippodamia convergens (Coleoptera: Coccinellidae). Ann Entomol Soc Am 75, 678-683.

Pliske TE, Eisner T (1969) Sex pheromone of the queen butterfly: biology. Science 164, 1170-1172.

Santos PHS, Silva MA (2008) Retention of vitamin C in drying processes of fruits and vegetables, A Review. Dry Technol 26, 1421-1437. 